\title{
Autoantibody and Viral Serologic Examinations in Multiple Sclerosis and Stroke
}

\author{
Multipl Skleroz ve İnmede Otoantikor İncelemesi ve Viral Serolojik İncelemeler
}

\author{
(- Beuy Joob1, (1) Viroj Wowanitkit ${ }^{2}$ \\ 1Sanitation Medical Academic Center, Bangkok, Thailand \\ 2Dr. DY Patil University, Pune, India
}

Keywords: Autoantibody, viral, serology examination, multiple sclerosis, stroke

Anahtar Kelimeler: Otoantikor, viral, seroloji incelemesi, multipl skleroz, inme

\section{Dear Editor,}

We read the publication on "the value of autoantibody and viral serologic examinations in the differential diagnosis of multiple sclerosis (MS) and stroke" with great interest (1). Şair et al. (1) concluded that "information obtained from autoantibody and viral serologic tests does not affect the diagnosis of MS and stroke. Performing these tests for routine screening is considered worthless unless there is an important finding regarding clinical disease". The report in this study is in contrast to a previous study by Prineas and Parratt (2). Some facts should be addressed. Focusing on autoantibody and viral serologic examinations, the methods of analysis is related to diagnostic property and the local seroepidemiology also affects the detection rate. Regarding the advantage of using a serologic test as screening, Karussis (3) noted that the test could help improve the accuracy of diagnosis and also contribute to the identification of the patients with clinically or radiologically isolated syndromes. There is a clinical role of serologic tests in the differential diagnoses of MS. Serologic tests should be performed at least once. In the event that there may be another disease that mimics MS, second serologic tests must be performed again within 6 months $(3,4)$. To assess the exact advantage of serologic tests, there should be additional costeffectiveness analysis comparing the use and non-use of the test.
Ethics

Informed Consent: This is not a report or study on patient or animal requires.

Peer-review: Externally peer-reviewed.

\section{Authorship Contributions}

Surgical and Medical Practices: B.J., V.W., Concept: B.J., V.W., Design: B.J., V.W., Data Collection or Processing: B.J., V.W., Analysis or Interpretation: B.J., V.W., Literature Search: B.J., V.W., Writing: B.J., V.W.

Conflict of Interest: No conflict of interest was declared by the authors.

Financial Disclosure: The authors declared that this study received no financial support.

\section{References}

1. Şair A, Akyıldız UO, Korkmazgil B, Kıylığlu N. The value of autoantibody and viral serologic examinations in the differential diagnosis of multiple sclerosis and stroke. Turk J Neurol 2019;25:208-213.

2. Prineas JW, Parratt JDE. Multiple sclerosis: Serum anti-CNS autoantibodies. Mult Scler 2018;24:610-622.

3. Karussis D. The diagnosis of multiple sclerosis and the various related demyelinating syndromes: a critical review. J Autoimmun 2014;48-49:134142 .

4. Brownlee WJ, Hardy TA, Fazekas F, Miller DH. Diagnosis of multiple sclerosis: progress and challenges. Lancet 2017;389:1336-1346.

\footnotetext{
Address for Correspondence/Yazışma Adresi: Beuy Joob MD, Sanitation Medical Academic Center, Bangkok, Thailand Phone: +024564789 E-mail: beuyjoob@hotmail.com ORCID: orcid.org/0000-0002-5281-0369

Received/Geliş Tarihi: 25.12.2019 Accepted/Kabul Tarihi: 30.08 .2020

${ }^{\circ}$ Copyright 2020 by Turkish Neurological Society Turkish Journal of Neurology published by Galenos Publishing House.
} 